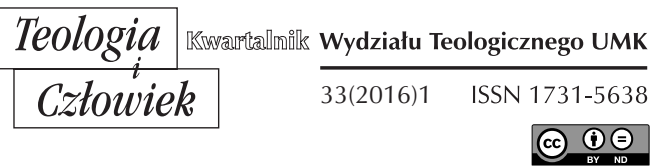

DK. BARTOSZ ADAMSKI*

TORUŃ

\title{
OGÓLNOPOLSKA KONFERENCJA NAUKOWA „RODZINA - DAR, ZADANIE I NADZIEJA LUDZKOŚCl", TORUŃ, 19 LISTOPADA 2015 R.
}

DOI: http://dx.doi.org/10.12775/TiCz.2016.009

Święty Jan Paweł II w liście na XVIII Międzynarodowy Kongres Rodziny w 1994 r. napisał, że: „Rodzina jest prawdziwym fundamentem społeczeństwa i stanowi jedno z najcenniejszych dóbr ludzkości. Jest środowiskiem posiadającym najlepsze warunki do przekazywania wartości religijnych i kulturowych, które pomagają człowiekowi w ukształtowaniu własnej tożsamości. Dzisiaj instytucja rodziny przeżywa kryzys i jest także narażona na liczne niebezpieczeństwa, których celem jest pomniejszenie jej świętej godności i jej szczególnego znaczenia, jakie posiada w Kościele i społeczeństwie. Potrzeba więc odważnej i ofiarnej współpracy wszystkich ludzi dobrej woli, aby rodzinie współczesnej pomóc odkryć piękno i wielkość jej powołania: powołania do miłości i służby życiu”. Odpowiadając na przytoczone tu słowa papieża Polaka, Katedra Teologii Praktycznej Wydziału Teologicznego UMK w Toruniu, przy szczególnym wkładzie jej

* Dk. Bartosz Adamski jest alumnem Wyższego Seminarium Duchownego diecezji toruńskiej i studentem Wydziału Teologicznego UMK w Toruniu. 
członków: ks. dra hab. Zbigniewa Zarembskiego i ks. dra Sławomira Tykarskiego, zorganizowała ogólnopolską konferencję naukową „Rodzina dar, zadanie i nadzieja ludzkości”.

Cel konferencji trafnie ujął ks. dziekan prof. dr hab. Dariusz Kotecki w swoim przemówieniu otwierającym spotkanie. Zauważył on, że nauczanie Kościoła, przekazane m.in. w Katechizmie Kościoła Katolickiego i pismach Jana Pawła II, jednoznacznie charakteryzuje rodzinę jako podstawową komórkę życia społecznego i fundament cywilizacji miłości. Niestety w dzisiejszym świecie jej rola i koncepcja są coraz częściej kwestionowane. Dlatego istnieje potrzeba obrony rodziny przez ukazanie wielkiego znaczenia i dobra, jaki stanowi ona dla Kościoła, państwa i społeczeństwa. Z tego powodu na Wydziale Teologicznym, który oprócz zadań dydaktycznych i naukowych ma też misję ewangelizacyjną w Kościele, została zorganizowana konferencja ukazująca i potwierdzająca miejsce rodziny $\mathrm{w}$ świecie oraz jej powołanie do miłości, służby życiu i krzewienia wiary w Jezusa Chrystusa.

Spotkanie konferencyjne było skierowane do pracowników naukowych, doktorantów, studentów, duszpasterzy i wszystkich tych, którzy pragnęli powiększyć swoją wiedzę w dziedzinie familiologii. Przewidziane wystąpienia prelegentów poruszały zagadnienia dotyczące zaproponowanego tematu z punktu widzenia teologii, socjologii czy nawet psychologii, co spowodowało, że uczestnicy zjazdu mieli okazję do szerokiej i pogłębionej refleksji o rodzinie. Zaproszeni znakomici znawcy problematyki rodziny, pochodzący $\mathrm{z}$ różnych ośrodków naukowych w Polsce, przedstawiali efekty swoich badań naukowych w formie wykładów i komunikatów, a podczas trwania dwóch paneli dyskusyjnych, przy okazji odpowiedzi na zadane pytania, dzielili się swoimi doświadczeniami i spostrzeżeniami wynikającymi z ich pracy zawodowej lub duszpasterskiej.

Po uroczystej Mszy świętej w kaplicy Wydziału Teologicznego nastąpiło otwarcie konferencji przez dziekana Wydziału Teologicznego, ks. prof. dra hab. Dariusza Koteckiego. Następnie prowadzący obrady ks. dr hab. Zbigniew Zarembski po stosownym wprowadzeniu oddał głos prelegentom reprezentującym najważniejsze teologiczne ośrodki naukowe w Polsce. Jako pierwszy wystąpił ks. bp dr hab. Wiesław Śmigiel (KUL) z referatem Ewangelizacyjne zadania rodziny, który w świetle nauczania Soboru Watykańskiego II i myśli św. Jana Pawła II ukazywał 
rodzinę chrześcijańską jako wspólnotę wierzącą i ewangelizującą. Zostało tu podkreślone, że rodzina na mocy sakramentu chrztu udzielonego jej członkom jest wezwana do realizacji funkcji prorockiej, kapłańskiej i królewskiej w Kościele i środowisku jej życia. Całościowe spojrzenie na rodzinę od strony socjologii, prawa i polityki w rzeczywistości państw europejskich ukazał kolejny zaproszony gość - dr hab. Elżbieta Osewska (UKSW) w referacie zatytułowanym Możliwości i zagrożenia polityki rodzinnej $w$ krajach Unii Europejskiej. Ze szczególną sympatią słuchaczy został przyjęty wykład ks. prof. dra hab. Bronisława Mierzwińskiego (UKSW) - wybitnego familiologa, który przedstawił teologię Jana Pawła II poruszającą zagadnienia płciowości i cielesności jako antidotum dla zagubionej rodziny, wezwanej do wierności Chrystusowi i Jego nauczaniu.

W pierwszym wystąpieniu po przerwie kawowej aspekt katechetyczny badań nad rodziną w dzisiejszym świecie ukazał ks. prof. dr hab. Józef Stala (UPJPII), który podkreślił rolę katechizacji zarówno dzieci, jak i rodziców w budowaniu chrześcijańskiej rodziny, uwzględniając kierunki jej przeobrażeń w ostatnich dziesięcioleciach. Temat jego przedłożenia brzmiał: Katecheza na rzecz rodziny XXI wieku. W kolejnym wystąpieniu dr hab. Maria Ryś (UKSW) podjęła się przedstawienia zagadnienia relacji osób tworzących podstawową komórkę życia społecznego, wygłaszając referat Budowanie więzi w rodzinie. Entuzjastycznie został przyjęty wykład Rodzina - triumf humanizacji nad technopolem dobrze znanego słuchaczom ks. prof. dra hab. Wojciecha Cichosza (UMK), który ukazał wartość rodziny chrześcijańskiej w dobie współczesnych przemian kulturowych zmierzających do negacji tradycyjnie uznawanych wartości, przy jednoczesnej absolutyzacji technicyzacji życia kierującej się osiąganiem coraz większej wydajności w podjętych działaniach.

Po zakończeniu części wykładowej przyszedł czas na komunikaty, z którymi wystąpili: dr Małgorzata Wiśniewska (zastępca Dyrektora Departamentu Spraw Społecznych i Zdrowia Urzędu Marszałkowskiego Województwa Kujawsko-Pomorskiego w Toruniu), Działania Samorzqdu Województwa Kujawsko-Pomorskiego na rzecz rodzin; ks. dr Mateusz Potoczny (UO), Obraz rodziny w papieskim magisterium po Soborze Watykańskim II; ks. mgr lic. Arkadiusz Muzolf (diecezjalny duszpasterz rodzin diecezji bydgoskiej), Duszpasterska troska o małżeństwa w kryzysie. 
Referaty zaprezentowane podczas konferencji miały wysokie walory poznawcze oraz zachęcały do rozmów o kwestiach dotyczących małżeństwa i rodziny. Prelegenci jednoznacznie podkreślali niezastąpioną rolę rodziny w budowaniu społeczeństwa opartego na wartościach religijnych i kulturowych, które w gąszczu różnorakich informacji i poglądów umożliwiają dzisiejszemu człowiekowi odnalezienie własnej tożsamości. $\mathrm{Z}$ tego powodu rodzina jawi się jedno z najcenniejszych dóbr ludzkości. Zaproszeni goście zwrócili też uwagę na liczne niebezpieczeństwa uderzające w godność i tradycyjny kształt podstawowej komórki społecznej, przy czym zgodnie stwierdzili, że najlepiej obronić ją może przed nimi współpraca wszystkich środowisk żyjących wartościami Ewangelii, które dzisiejszym społeczeństwom pomagają odkryć piękno i wielkość rodziny powołanej do miłości oraz służby życiu. 